an appreciable distance from the base of radius. This wing also shows the unity at the base of the wing of the two main branches of cubitus.

In the examination of a considerable number of wings from various orders of insects I have noted that anal veins arise from certain tracheal trunks or often apparently from one main trunk which divides at the base of the wing into several or many branches or rays; and that this main anal trunk is distinct from the main trunk or trunks which run into the pre-anal area of the wing, and which are the foundations of the principal longitudinal veins of the preanal area. In the wing of Hexagenia the veins corresponding to those veins marked "anal" in figure 4 are supplied with tracheae from one main trunk, the anal area trunk, while the first vein in front of these anal veins (called by me part of cubitus) does not receive a branch from this main anal trunk.

\title{
ON THE NEST AND PARASITES OF PROSOPIS VARIFRONS CRESSON.
}

By A. DAvidson, M. D., Los ANGEles, CAL.

This bee and Ceratina dupla are the most common ones that tunnel in the shoots of the elder and mustard in this locality. The cells are built in stems which the parent herself has hollowed out, and measure on an average 4 lines long, by 2 or 3 wide. They are lined with a thin, transparent layer of silk which is spun by the parent bee, and are filled three-fourths full with the light yellow semi-fluid bee-food. The egg is laid on top of this mass, and the cell is closed by the same silken tissue which, in its turn, forms the base of the succeeding cell. The last of the series, when finished, is further protected by a layer of pith of variable depth. The cells are probably normally built contiguously, but a few sometimes have partitions of pith, which may be the work of more than one bee.

Two broods at least are produced annually. By splitting the twigs containing the cells I was enabled to watch the larvae pass through their various stages, and in a series gathered on May 5 at Manzana, in the Antelope Valley, all of which were apparently newly constructed, the food was consumed in 8 days after the hatching of the egg. The larvae at this stage are quite active, and in their restlessness a few of them burst through the lining of the cell on the exposed side and made their escape. During this period of activity they void a small quantity of excrement which, being limited to one end of the cell, simulates an artificial partition between the cells.

In from four to six days after the food was consumed they passed into the pupa stage, and on June 9th with two exceptions all had taken their flight, the time occupied in passing 
through all the stages being but thirtyfive days. Whether one or inore broods are raised before the one that lives through the winter, I am unable to say, though it may reasonably be presumed that such is the case. The last brood remains in the larval stage throughout the winter, usually emerging as adults in the latter half of April.

The parasites affecting this insect are all of small size, and one cell in four on an average is affected. Those bred by the writer are as follows:

Chrysis parvula Fabr. Two specimens.

Encyrtus sp? These tiny parasites had attacked the larva of the bee, consuming the whole interior and leaving the skin intact. Within this covering the pupae of the parasite, from Io to i 5 in number, were closely packed. The adults issued in the last week of February and the first week in May.

Aetroxys analis Ashmead n. sp. I I specimens.

q. Length $5.5 \mathrm{~mm}$. Bronzy green, scaly punctate, the tip of the abdomen yellowish; scape and legs, except coxae, ferruginous, the knees, tips of tibiae and tarsi more yellowish. Wings hyaline, the veins pale brown, the marginal vein about one and onehalf times as long as the stigmal, the post marginal vein as long as or slightly longer than the marginal. Abdomen very long acuminate, fully twice as long as the head and thorax united.

§. Length 2 to $2.5 \mathrm{~mm}$. Differs only in the shape of the abdomen which is elongate and only one-third longer than the head and thorax united, while the flagellum is filiform, pubescent, the first joint the longest, joints 3 to 5 subequal, about twice as long as thick.

Mr. Ashmead, in a note appended to this description, says: "The antennae in the $q$ are broken off at the pedicel, and I am therefore unable to tell to what subgenus of Aetroxys it belongs. The very long abdomen, which is tipped with yellow, readily distinguishes the species."

These eleven specimens were bred from six cells, five occupying one, and two each of the other three cells. On pupating they adhered together by the tip of the abdomen in one mass. All issued May 29.

\section{THE NUMBER OF STAGES IN APATELODES TORREFACTA.}

\section{BY HARRISON G. DYAR, NEW YORK CITY.}

I have already referred to the varying number of stages in this species (Psyche, vi, 146) as found by different authors; Miss Soule finding five and Dr. Packard six, while I presented evidence indicating eight stages. I returned to the subject last summer, as I succeeded in obtaining eggs by the assistance of
Mr. Jacob Doll from whom I purchased living pupae and. Miss Emily L. Morton who very kindly attended to the mating of the moths bred from them. The larvae exhibited five stages, but a consideration of the width of the head makes the whole matter clear. I gave the following series as probable, in my 

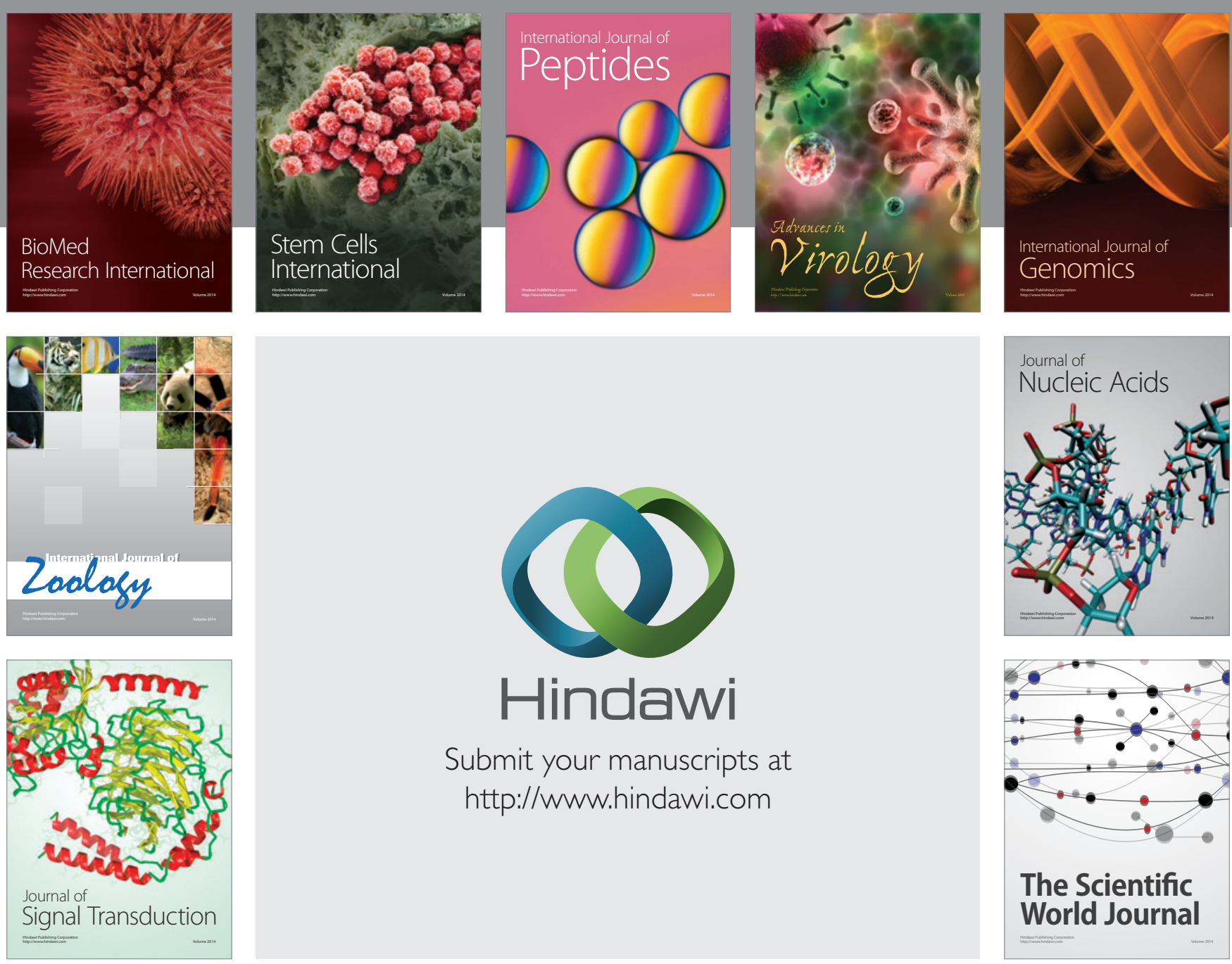

Submit your manuscripts at

http://www.hindawi.com
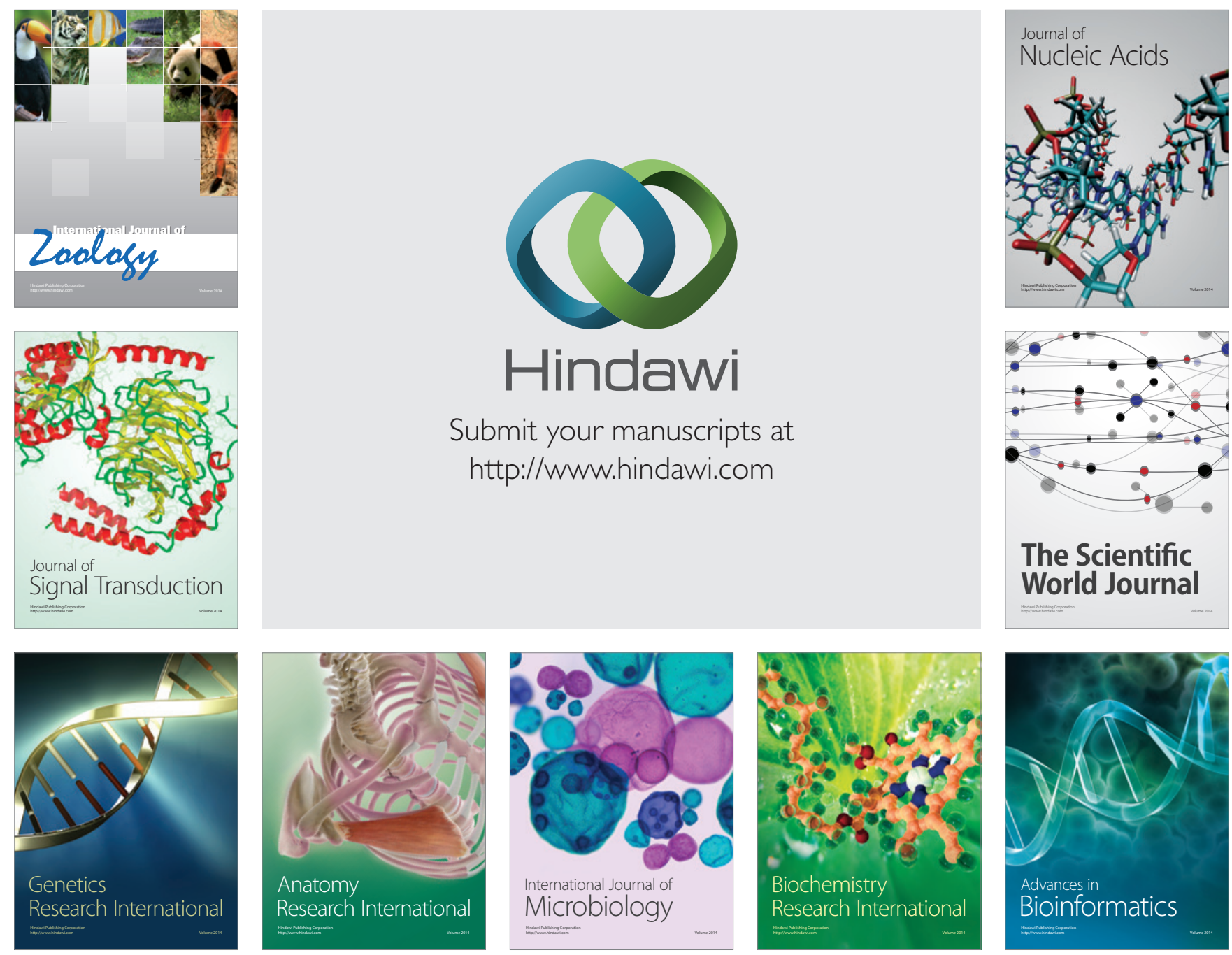

The Scientific World Journal
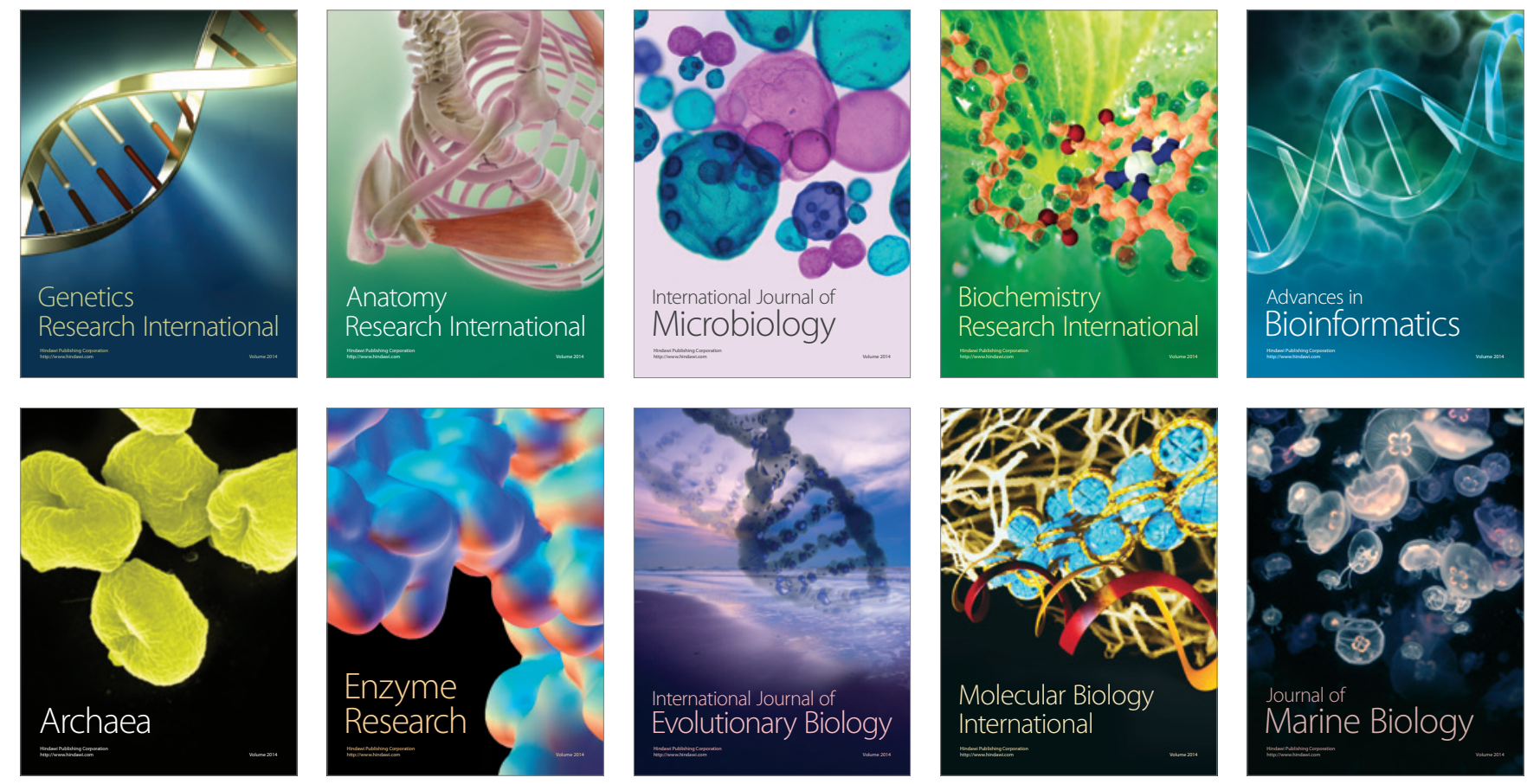